\title{
Pengaruh Dosis Kompos dengan Stimulator Trichoderma terhadap Pertumbuhan dan Produksi Tanaman Jagung (zea mays $l$.) Varietas Pioner -11 pada Lahan Kering
}

\author{
Retno Afitin dan Sri Darmanti \\ Laboratorium Biologi Struktur dan Fungsi Tumbuhan, Jurusan Biologi FMIPA Undip
}

\begin{abstract}
Abstrak
Lahan kering di Indonesia sangat luas. Sifat lahan kering yang kurang subur dengan tingkat erosi yang tinggi dan rendahnya pasokan air menyebabkan pemanfaatan lahan kering belum optimal. Kompos sebagai salah satu pupuk organik dengan bahan baku yang tersedia cukup banyak merupakan alternatif yang tepat untuk digunakan dalam memanfaatkan lahan kering sebagai lahan pertanian. Penelitian menggunakan Rancangan Acak Lengkap dengan 4 perlakuan berupa dosis pemupukan, yaitu : D0 : 0 ton / Ha (kontrol), D1 : 15 ton / Ha, D2 : 30 ton / Ha dan D3 : 45 ton / Ha. Data yang diperoleh dianalisis dengan Analisis of Varians (Anava), bila terdapat beda nyata dilanjutkan dengan uji Beda Nyata terkecil (BNT) pada taraf kepercayaan 95\%. Dari hasil penelitian dapat disimpulkan bahwa kompos dengan stimulator tricoderma berpengaruh meningkatkan pertumbuhan dan produksi tanaman jagung pada lahan kering dan dosis $3 \mathrm{~kg} / \mathrm{m}^{2}$ merupakan dosis optimal untuk pertumbuhan dan produksi jagung.
\end{abstract}

Kata kuci : Kompos, Stimulator, Trichodema, Produksi, Zea mays L. var Pioner-11.

\begin{abstract}
The dry farming in Indonesia very wide. The dry farming is the low of fertility with high erosion level and low of water suply cause exploiting of dry farming not yet optimal. Compost as one of the organic fertilizer with available raw material quite a lot, are alternatives to be used in exploiting dry farming as agriculture farm. Research use Random Device Complete with 4 treatment in the form of fertilization dose , that is : D0 : 0 ton / Ha ( control), D1 : 15 ton / Ha, D2 : 30 ton / Ha and D3 : 45 ton / Ha. Collected data were analysed using analysis of variance (Anava) followed with Different test of Smallest Reality ( BNT) at 95\% significance level. From research result can be concluded that compost with tricoderma stimulator have an effect on to improve maize crop production and growth at dry farming and dose $3 \mathrm{~kg} / \mathrm{m} 2$ is optimal dose for the growth and production of maize crop.
\end{abstract}

Key world : Compos, Stimulator, Trichoderma, Production, Zea mays L. var Pioner-11.

\section{PENDAHULUAN}

Pemanfaatan lahan kering di Indonesia saat ini masih belum optimal. Hal itu disebabkan karena sifat-sifat lahan kering yang mempuyai sumber air terbatas, tingkat kesuburan rendah dan tingkat erosi yang tinggi. Pemberdayaan lahan kering untuk agribisnis bukan saja dapat menambah pendapatan para petani tapi juga dapat memberi manfaat dalam konservasi tanah. Pemberdayaan lahan kering dapat dilakukan dengan pengembangan komoditas pertanian yang sesuai dengan tata guna lahan (Irawan dan Pranadji, 2002). Komoditas pertanian yang biasa ditanam pada lahan kering yaitu ubi kayu, jagung dan kacang tanah.

Jagung mampu hidup pada lahan kering. Selain itu, jagung merupakan komoditi pangan yang sangat penting setelah padi. Sebagai sumber karbohidrat kedua setelah beras, jagung memegang peranan penting sebagai bahan pangan, makanan ternak dan bahan baku industri. Disamping itu, kebutuhan jagung setiap tahun semakin meningkat, maka perlu adanya upaya untuk meningkatkan produksi jagung. Salah satu upaya meningkatan produksi jagung pada lahan kering adalah 
perbaikan lahan pertanian dengan pemberian pupuk organik (Suprapto, 1998).

Pupuk organik terdiri atas pupuk kandang, pupuk hijau dan pupuk kompos. Kompos merupakan salah satu jenis pupuk organik yang terjadi karena proses penghancuran bahan-bahan organik hasil kerjasama faktor lingkungan dan mikroorganisme (Syarief, 1986). Kompos memiliki unsur hara lengkap baik makro maupun mikro dan sangat dibutuhkan tanaman untuk pertumbuhan dan produksi. Tanaman menyerap unsur hara dari dalam tanah dengan jumlah dan perbandingan yang berbeda-beda tergantung jenis tanamannya. Kebutuhan hara ini dapat dipenuhi dengan penambahan hara ke tanah melalui pemupukan. Kompos dapat memperbaiki sifat fisik tanah seperti struktur tanah, tekstur tanah, memperbaiki tata air dan udara tanah, memperbaiki suhu tanah menjadi lebih stabil, mempertinggi daya ikat tanah terhadap zat hara sehingga tidak mudah larut oleh air. Selain itu kompos dapat memperbaiki sifat kimiawi tanah karena daya absorbsi dan daya tukar kation yang besar. Kompos juga dapat memperbaiki sifat biologi tanah yaitu memperbaiki kehidupan mikroorganisme di dalam tanah. Hal ini sangat baik untuk konservasi tanah pada lahan kering.

Pembuatan kompos dapat terjadi lewat prose alami. Bahan-bahan organik akan membusuk atau lapuk menjadi kompos dan proses ini biasanya membutuhkan waktu cukup lama yaitu \pm 90 hari (Murbandono, 1990). Mengingat kebutuhan kompos yang semakin meningkat, maka perlu suatu langkah untuk mempercepat pengomposan yaitu dengan penambahan stimulator selama pengomposan. Salah satu stimulator yang dapat digunakan adalah Trichoderma. Trichoderma merupakan salah satu jenis fungi atau jamur yang menghasilkan enzim selulase serta enzim lain yang mendegradasi kompleks polisakarida. Kandungan enzim selulase Trichoderma dapat mendegradasi selulosa sehingga pembusukan bahan organik akan terjadi dengan cepat. Potensi ini sangat bermanfaat bagi sektor pertanian karena dapat digunakan dalam proses pengomposan. Pengomposan dengan stimulator Trichoderma biasanya membutuhkan waktu sekitar 21-45 hari (Cuevas, 1997). Dari latar belakang tersebut diatas maka perlu dikaji bagaimanakah pengaruh pemberian kompos dengan stimulator Trichoderma terhadap pertumbuhan dan produksi tanaman jagung pada lahan kering dan pada dosis berapakah kompos dengan stimulator Trichoderma ini dapat menghasilkan pertumbuhan dan produksi tanaman jagung paling tinggi pada lahan kering.

\section{BAHAN DAN METODE}

Penelitian menggunakan Rancangan Acak Lengkap dengan 4 perlakuan berupa dosis pemupukan, yaitu : D0 : 0 ton / Ha (kontrol), D1 : 15 ton / Ha, D2 : 30 ton / Ha dan D3 : 45 ton / Ha.

Pupuk kompos dibuat dari bahan sampah dengan stimulator Trichoderma dengan konsentrasi $1 \%(\mathrm{~b} / \mathrm{b})$, dengan masa inkubasi 6 minggu. Media tanam dibuat dengan membuat petak tanah seluas $1 \times 1 \mathrm{~m}^{2}$, kemudian dicampur pupuk kompos dengan dosis sesuai dosis perlakuan, yaitu : D0 : 0 ton / Ha (kontrol), D1 : 15 $\mathrm{kg} / \mathrm{m}^{2}, \mathrm{D} 2: 3 \mathrm{~kg} / \mathrm{m}^{2}$ dan D3 : 4,5 $\mathrm{kg} / \mathrm{m}^{2}$. Selanjutnya dilakukan pembibitan, pemeliharaan, seleksi dan pemberantasan gulma. Pemanenan dilakukan setelah tanaman berumur 55 hari dan diamati parameter sebagai berikut : tinggi tanaman $(\mathrm{cm})$, berat kering tanaman (gr), berat kering biji (gr) dan jumlah biji. Sebagai parameter pendukung adalah $\mathrm{C} / \mathrm{N}$ rasio, kandungan $\mathrm{P}, \mathrm{K}$ dan $\mathrm{N}$. Data yang diperoleh dianalisis dengan Analisis of Varians (Anava), bila terdapat beda nyata dilanjutkan dengan uji Beda Nyata terkecil (BNT) pada taraf uji $5 \%$.

\section{HASIL DAN PEMBAHASAN}

Dari penelitian mengenai pengaruh dosis kompos dengan stimulator Trichderma terhadap pertumbuhan dan produksi tanaman jagung didapatkan hasil sebagai berikut : 
Tabel.1 Rerata tinggi tanaman $(\mathrm{cm})$, berat kering tanaman (g), jumlah biji dan berat kering biji (g) tanaman jagung setelah perlakuan kompos dengan stimulator Trichoderma.

\begin{tabular}{lcccc}
$\begin{array}{l}\text { Dosis } \\
\text { Parameter }\end{array}$ & DO & D1 & D2 & D3 \\
& & & & \\
\hline $\begin{array}{l}\text { Tinggi } \\
\text { tanaman } \\
(\mathrm{cm})\end{array}$ & $93,87^{\mathrm{a}}$ & $105,57^{\mathrm{b}}$ & $117,17^{\mathrm{c}}$ & $112,17^{\mathrm{c}}$ \\
$\begin{array}{l}\text { Berat kering } \\
\text { tanaman }(\mathrm{g})\end{array}$ & $144,77^{\mathrm{d}}$ & $200,47^{\mathrm{e}}$ & $216,93^{\mathrm{f}}$ & $226,73^{\mathrm{f}}$ \\
$\begin{array}{l}\text { Jumlah biji } \\
\text { Berat kering }\end{array}$ & $237,53^{\mathrm{g}}$ & $256,47^{\mathrm{g}}$ & $319,60^{\mathrm{h}}$ & $366,67^{\mathrm{i}}$ \\
biji (g) & $78,50^{\mathrm{j}}$ & $120,97^{\mathrm{k}}$ & $156,17^{1}$ & $155,77^{1}$ \\
\hline $\begin{array}{l}\text { Keterangan : angka yang diikuti huruf yang sama pada } \\
\text { satu baris menunjukkan berbeda tidak nyata. }\end{array}$
\end{tabular}

Dari analisis anova menunjukkan bahwa kompos dengan stimulator Trichoderma berpengaruh nyata terhadap pertumbuhan dan produksi tanaman jagung. Tabel 1 menunjukkan bahwa perlakuan kompos dengan stimulator Trichderma terhadap tinggi tanaman jagung berbeda nyata dengan kontrol. Uji beda nyata terkecil (BNT) untuk tinggi tanaman menyatakan bahwa D1, D2 dan D3 berbeda nyata dengan control (D0). D1 berbeda nyata dengan D2 dan D3. Sedangkan antara D2 dan D3 tidak berbeda nyata. Sementara Uji BNT untuk berat tanaman jagung menunjukkan bahwa antara D1, D2 dan D3 berbeda nyata dengan D0. D1 berbeda nyata dengan D2 dan D3. Sedangkan antara D2 dan D3 tidak berbeda nyata. Dalam bentuk histogram pertumbuhan tanaman dapat dilihat sebagai berikut:

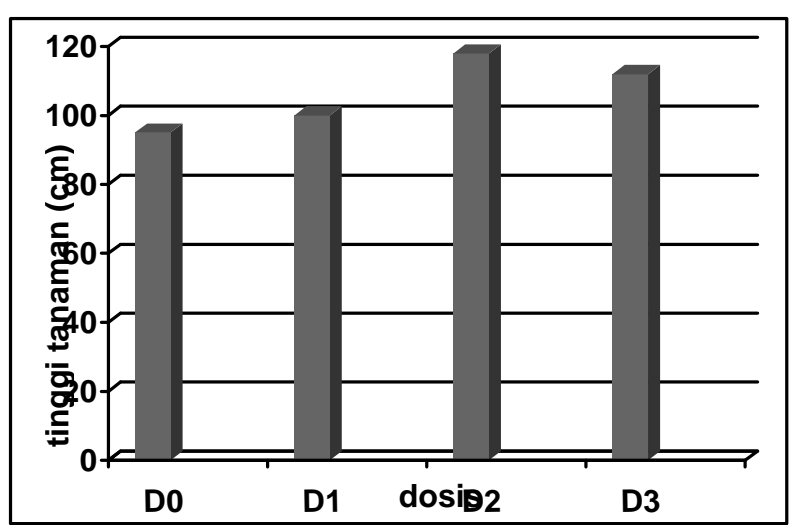

Gambar 1. Rerata tinggi tanaman (cm) setelah perlakuan kompos dengan stimulator Trichoderma.

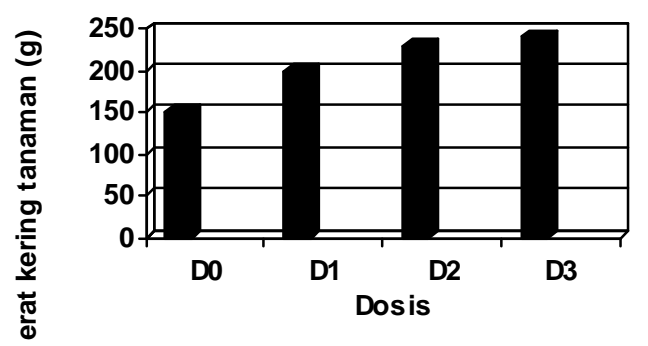

Gambar 2. Rerata berat kering tanaman (g) setelah perlakuan kompos dengan stimulator Trichoderma.

Hasil dari perlakuan D0, D1, D2 dan D3 yang diamati memberikan informasi bahwa pemberian kompos dengan stimulator Trichoderma menyebabkan pertumbuhan tanaman meningkat dengan semakin tingginya dosis. Namun pada D2 sudah menunjukkan pertumbuhan yang optimal.

Hasil penelitian menyatakan bahwa dosis $1,5 \mathrm{~kg} / \mathrm{m}^{2}$ (D1) sudah berpengaruh nyata pada berat tanaman dan tinggi tanaman. Hal ini disebabkan pemberian kompos dengan stimulator Trichoderma dapat meningkatkan kandungan hara pada tanah. Dari hasil analisis kandungan unsur hara kompos dengan stimulator Trichoderma dapat dilihat pada tabel 2 
Tabel 2. Kandungan unsur N, P dan K tanah sebelum perlakuan dan setelah perlakuan kompos dengan stimulator Trichoderma pada minggu ke-6.

\begin{tabular}{lccc} 
Jenis stimulator & \multicolumn{3}{l}{ Kandungan unsure hara (\%) } \\
\cline { 2 - 4 } & $\mathrm{N}$ & $\mathrm{P}$ & $\mathrm{K}$ \\
\hline Kontrol & 1,4 & 0,095 & 0,60 \\
Trichoderma & 1,92 & 0,105 & 0,92 \\
\hline
\end{tabular}

Dari Tabel 2 dapat diketahui bahwa kompos dengan stimulator Trichoderma dapat meningkatkan kandungan hara tanah. Meningkatnya dosis pemberian kompos akan menyebabkan semakin tinggi pula kandungan unsur hara pada tanah. Unsur hara tersebut akan digunakan oleh tanaman untuk melangsungkan hidupnya diantaranya proses fotosintesis dan respirasi (Harjadi, 1979). Menurut Agustina (2004) dan Poerwidodo (1993) nitrogen, fosfor dan kalium dibutuhkan dalam jumlah besar pada setiap tahap pertumbuhan tanaman khususnya pada saat pertumbuhan vegetatif seperti dalam perkembangan batang dan daun.

Unsur nitrogen, fosfor dan kalium sangat penting bagi tanaman karena berperan dalam pembentukan asam amino, protein, asam nukleat dan klorofil. Klorofil berperan dalam fotosintesis yang menghasilkan karbohidrat. Karbohidrat sederhana yang dihasilkan dari proses fotosintesis akan digunakan untuk proses respirasi menghasilkan ATP, membentuk lipid, asam nukleat, dan protein yang selanjutnya digunakan untuk membentuk batang, daun, akar dan jaringan baru.

Selain itu, kompos mempunyai manfaat lain yaitu memperbaiki sifat fisik tanah. Secara lengkap tingkat erodibilitas tanah sebagai salah satu sifat fisik tanah dapat dilihat pada tabel 3 :
Tabel 3. Tingkat erodibilitas tanah sebelum dan setelah pemberian kompos dengan Stimulator Trichoderma.

\begin{tabular}{|c|c|c|c|}
\hline No & $\begin{array}{l}\text { Waktu pemberian } \\
\text { kompos }\end{array}$ & $\begin{array}{l}\text { Tingkat } \\
\text { erodiibilitas } \\
\text { (ton/ha) }\end{array}$ & Keterangan \\
\hline 1 & $\begin{array}{l}\text { Sebelum } \\
\text { perlakuan }\end{array}$ & 66,37 & Tinggi \\
\hline 2 & $\begin{array}{l}\text { Saat awal tanam } \\
\cdot \text { Kontrol } \\
\text {-Trichoderma }\end{array}$ & $\begin{array}{l}47,55 \\
54,16\end{array}$ & $\begin{array}{l}\text { Agak Tinggi } \\
\text { Agak Tinggi }\end{array}$ \\
\hline 3 & $\begin{array}{l}\text { Setelah panen : } \\
\text { - Kontrol } \\
\text { - Trichoderma }\end{array}$ & $\begin{array}{c}33,08 \\
0,61\end{array}$ & $\begin{array}{c}\text { Sedang } \\
\text { Amat Rendah }\end{array}$ \\
\hline
\end{tabular}

Lahan yang digunakan untuk penanaman jagung pada penelitian ini adalah lahan kering. Lahan kering umumnya memiliki indeks erodibilitas yang tinggi. Hal itu dapat dilihat dari data erodibilitas tanah sebelum dan setelah panen pada table 3. Data pada tabel 3 menunjukkan bahwa tanah yang digunakan sebagai media mempunyai tingkat erodibilitas 66,37. Tanah dengan indeks erodibilitas tinggi berarti mudah tererosi. Makin terkikisnya lapisan top soil tanah maka banyak unsur hara akan hilang. Akibatnya tanah menjadi kurus dan pasokan mineral serta hara lain yang dibutuhkan tanaman akan berkurang. Berkurangnya pasokan mineral dan unsur hara maka proses metabolisme dalam tubuh tanaman terhambat sehingga pertumbuhan tanaman akan menurun.

Setelah penambahan kompos dengan stimulator Trichoderma, indeks erodibilitas tanah menjadi 0,61 yang berarti agak lambat. Penurunan pada indeks erodibilitas disebabkan oleh bahan organik yang terkandung pada kompos dengan stimulator Trichoderma yang cukup tinggi yaitu sebesar 37,22 (Tabel 4). 
Tabel 4. Kandungan bahan organik tanah setelah perlakuan kompos dengan Stimulator Trichoderma

\begin{tabular}{llcc}
\hline No & Bahan stimulator & \multicolumn{2}{c}{ Bahan Organik (\%) } \\
\cline { 3 - 4 } & & $\begin{array}{c}\text { Sebelum } \\
\text { tanam }\end{array}$ & $\begin{array}{c}\text { Setelah } \\
\text { tanam }\end{array}$ \\
\hline 1 & Tanpa kompos (control) & 11,25 & 2,54 \\
2 & Trichoderma & 37,22 & 2,74 \\
\hline
\end{tabular}

Tabel 4 menunjukkan bahwa kandungan bahan organik setelah penambahan kompos dengan stimulator Trichoderma lebih tinggi dibanding kontrol. Menurut Sutedjo dan Kartasapoetra (2004), meningkatnya kandungan bahan organik pada tanah dapat menurunkan tingkat erodibilitas tanah karena bahan organik dapat mengikat dan mempertahankan kemantapan struktur tanah pada tanah. Tanah yang ringan atau mudah tererosi akan menjadi lebih berat sehingga tidak mudah tererosi dengan penambahan kompos. Dengan demikian pemberian kompos Trichoderma dapat mencegah erosi tanah.

Selain perbaikan sifat fisik, kompos juga memperbaiki sifat kimia tanah. Penambahan kompos menyebabkan daya absorbsi tanah dan daya tukar kation menjadi lebih besar. Hal ini berpengaruh pada penyerapan hara tanah oleh tanaman. Dengan meningkatnya daya absorbsi dan Kapasitas Tukar Kation (KTK) maka penyerapan hara lebih efektif, sehingga dapat meningkatkan pertumbuhan dan produksi tanaman.

Dari segi biologi tanah kompos dapat menambah jumlah dan memperbaiki kehidupan mikroorganisme tanah. Mikroorganisme tanah ini berguna untuk meningkatkan hara melalui proses fikasi dan menambah udara tanah. Dengan banyaknya mikroorganisme tanah secara tidak langsung tanah menjadi lebih subur dan sangat baik untuk pertumbuhan tanaman.

Pemberian kompos pada dosis $4,5 \mathrm{~kg} / \mathrm{m}^{2}$ (D3) dibandingkan pada dosis $5 \mathrm{~kg} / \mathrm{m}^{2}$ (D2) tidak menunjukkan peningkatan pada pertumbuhan tanaman (berat tanaman dan tinggi tanaman). Hal itu menunjukkan bahwa batas optimal pemberian kompos untuk mendapatlan pertumbuhan yang maksimal adalah $3 \mathrm{~kg} / \mathrm{m}^{2}$ (D2). Pada dosis $3 \mathrm{~kg} / \mathrm{m}^{2}$ (D2), pemberian kompos sudah mencapai tingkat optimum untuk dapat dimanfaatkan tanaman.
Tanaman mengambil unsur hara hanya sampai batas tertentu sesuai kebutuhannya, bila terdapat berlebih maka tidak akan diabsorbsi oleh tanaman.

Hasil penelitian mengenai produksi tanaman jagung dengan parameter jumlah biji dan berat basah biji jagung menunjukkan hasil yang berbeda nyata. Berdasarkan uji BNT untuk jumlah biji dapat diketahui bahwa D2 dan D3 berbeda nyata dengan D0. Sementara antara D0 dengan D1 tidak berbeda nyata untuk berat biji

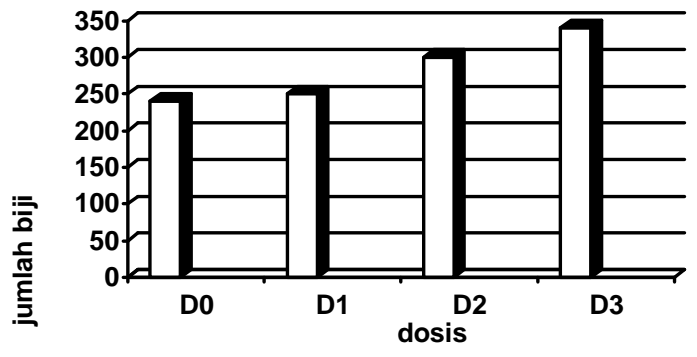

Gambar 3. Rerata jumlah biji setelah perlakuan kompos dengan stimulator Trichoderma.

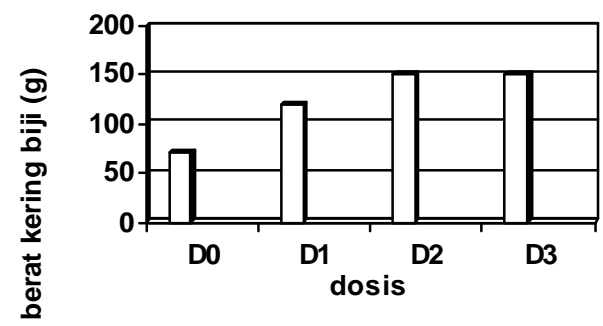

Gambar 4. Rerata berat kering biji (g) setelah perlakuan kompos dengan stimulator Trichoderma.

Hasil dari perlakuan D0, D1, D2 dan D3 yang diamati memberikan informasi bahwa pemberian kompos dengan stimulator Trichoderma menyebabkan produksi tanaman meningkat dengan semakin tingginya dosis. Namun seperti yang ditunjukkan pada Tabel 1 peningkatan berat biji hanya teradi pada tingkat pemberian dosis tertentu yaitu $3 \mathrm{~kg} / \mathrm{m}^{2}$ (D2). Perlakuan dosis 1,5 $\mathrm{kg} / \mathrm{m}^{2}$ (D1) sudah memberi pengaruh nyata pada berat biji (produksi tanaman). Hal ini disebabkan pemberian kompos dapat meningkatkan unsur hara pada tanah. Kandungan hara tanah yang cukup banyak pada penambahan kompos ini didukung 
oleh sifat fisik tanah dengan terhambatnya erosi tanah sehingga pencucian hara terhambat. Terhambatnya pencucian hara menyebabkan unsur hara dapat dipertahankan.

Kandungan hara pada tanah menyebabkan pertumbuhan vegetatif tanaman jagung menjadi baik. Pertumbuhan vegetatif baik, maka pertumbuhan generatif menjadi baik pula. Pada pertumbuhan vegetatif terjadi proses pembentukan jaringan dan organ seperti akar, batang dan daun yang semuanya akan digunakan untuk melangsungkan hidupnya. Akar akan menyerap air, hara dan mineral dari dalam tanah. Batang berperan dalam memberi kekuatan dan menyokong tubuh tanaman, sementara daun berperan dalam pembentukan makanan melalui proses fotosintesis. Hasil fotosintesis akan diedarkan keseluruh tubuh dan sisanya disimpan sebagai cadangan makanan.

Kebutuhan tanaman pada fase produksi akan terpenuhi dengan mudah bila pertumbuhan vegetatif tanaman maksimal. Pada fase produksi terjadi penumpukan cadangan makanan pada buah. Dengan pertumbuhan yang maksimal maka fotosintat dan cadangan makanan yang dihasilkan juga akan lebih banyak.

Selain itu, pada tanah setelah pemberian kompos dengan stimulator Trichoderma, kandungan unsur hara masih cukup banyak untuk pembentukan buah dan biji (fase reproduktif tanaman). Hal ini dapat dilihat dari kandungan hara tanah pada Tabel 2. Novizan (2004) menyatakan pada fase produksi ini membutuhkan unsur $\mathrm{N}$ karena pada fase ini kebutuhan hormone dan enzim cukup besar. Untuk merangsang pembentukan bunga, buah dan biji serta membuat biji menjadi lebih besar maka tanaman memerlukan unsur $\mathrm{P}$ dan untuk meningkatkan translokasi gula pada pembentukan pati dan protein (cadangan makanan) tanaman memerlukan unsur K. Semua unsur tersebut dapat terpenuhi dengan adanya penambahan kompos.

Sementara pemberian kompos pada dosis $4,5 \mathrm{~kg} / \mathrm{m}^{2}$ (D3) dibandingkan pada dosis $3 \mathrm{~kg} / \mathrm{m}^{2}$ (D2) tidak menunjukkan peningkatan pada berat biji. Tidak adanya peningkatan pertumbuhan tersebut menandakan bahwa batas optimal pemberian kompos untuk mendapatkan berat biji yang maksimal adalah $3 \mathrm{~kg} / \mathrm{m}^{2}$ (D2). Hal ini disebabkan oleh pemberian kompos yang sudah mencapai tingkat optimal untuk dapat dimanfaatkan tanaman. Tanaman mengambil unsur hara hanya sampai batas tertentu sesuai kebutuhannya, bila terdapat berlebih maka tidak akan dimanfaatkan oleh tanaman.

Menurut Novizan (2004) pemberian dosis pupuk harus tepat karena terdapat fenomena "Peningkatan Hasil yang Menurun". Fenomena tersebut berarti pemberian pupuk harus diberikan pada dosis yang tepat karena produktivitas tanaman dapat mencapai maksimal dengan pemberian pupuk pada dosis tertentu. Penambahan pupuk tak akan berpengaruh pada peningkatan produktivitas bahkan menambah biaya produksi sehingga pendapatan menurun.

\section{KESIMPULAN}

Dari hasil penelitian dapat disimpulkan bahwa kompos dengan stimulator Tricoderma berpengaruh meningkatkan pertumbuhan dan produksi tanaman jagung pada lahan kering dan dosis $3 \mathrm{~kg} / \mathrm{m}^{2}$ merupakan dosis optimal untuk pertumbuhan dan produksi jagung (Zea mays L. ) varieta Pioner-11.

\section{DAFTAR PUSTAKA}

Adisarwanto, T dan Y.E Widyastuti, 2001. Meningkatkan Produksi Jagung Lahan Kering, Sawah dan Pasang Surut. Penerbit Penebar Swadaya, Jakarta.

Agustina, L. 2004. Dasar Nutrisi Tanaman.

Penerbit Rineka Cipta. Jakarta.

Anonim, 1998. Composting Process Ecochem. An Earth Friendly Company.

Apriaji, W.H. 2004. Memproses Sampah. PT Penebar Swadaya. Jakarta.

Cuevas, V.C. 1997. Rapid Composting Tecnology In The Philippinnes: Its Role In Producing Good-Quality Organic Fertilizers. Intitute Of Biological Scienes (IBS). Philippines.

Goldworthy, P.R. dan N.M Fisher.1992. Fisiologi Tanaman Budidaya Tropik, Universitas Gajah Mada Press. Yogyakarta.

Harjadi. S.S. 1979. Pengantar Agronomi. Penerbit PT Gramedia, Jakarta.

Harman, G.E. 2004. Trichoderma spp. Including $T$. harzianum, T. viride, T. koningil, $T$. Hamatum and Other spp. Denteromyeeies, 
Monilialea (asexual Clasification System). Comell University, Geneva, NY 14456.

1996. Trichoderma for Biocontrol of Plant Pathogen: From Basic Research to Commercialized Products. Departemens of Horticultural Science and of Plant Pathology Cornell University NYSAES, Geneva, NY 14456.

Irawan, B. dan Tri Pranadji. 2002. Pemberdayaan Lahan Kering untuk Pengembangan Agribisnis Berkelanjutan. FAE Volume 20. No. $2 ; 60-76$.

Lingga. P. dan Marsono. 2004. Petunjuk Penggunaan Pupuk. PT Penebar Swadaya, Jakarta.

Marzuki, A.R dan Suprapto. 2004. Bertanam Jagung. Edisi Revisi. Penebar Swadaya, Jakarta.

Murbandono, H.S.L. 1990. Kompos PT Penebar Swadaya. Jakarta.

--------,2004. Membuat Kompos. Edisi Revisi. PT Penebar Swadaya Jakarta.

Novizan. 2004. Petunjuk Pemupukan yang Efektif. Agro Media Utama. Jakarta.

Nyakpa, M.Y. 1988. Kesuburan Tanah. Penerbit Universitas Lampung.

Poerwidodo, M. 1993. Telaah Kesuburan Tanah. Penerbit Angkasa, Bandung.

Setyaningsih. 1990. Studi Pengaruh Trichoderma viride dan Scleroderma sp. Terhadap Pertumbuhan semai Eucalyptus alba Reinw Pada Media Serbuk Gergaji Meranti Merah dan Kelapa. Jurusan Manajemen Hutan Fakultas Kehutanan Institut Pertanian Bogor. Bogor.

Sitompul, S.M. 1995. Analisis Pertumbuhan Tanaman Gadjah Mada. University Press.Yogyakarta.

Suprapto. 1998. Bertanam Jagung. Penerbit Penebar Swadaya. Jakarta.

Sutedjo. M. M. 1999. Pupuk dan Cara Pemupukan. Penerbit Rineka Cipta. Jakarta.

Sutedjo. M. M. dan A.G. Kartasapoetra. 2002. Pengantar Ilmu Tanah Terbentuknya Tanah dan Tanah Pertanian. Edisi Baru. Penerbit Rineka Cipta Jakarta.

Sutoro. 1988. Budidaya Tanaman Jagung. Balai Penelitian Tanaman Pangan. Bogor.

Syarief, E.S. Kesuburan dan Pemupukan Tanah Pertanian. Penerbit Pustaka Buana, Bandung.

Tjitrosoepomo, G. 1993. Taksonomi Umum Dasar-dasar Taksonomi Tumbuhan.Gadjah Mada University Press. Yogyakarta.

Williams, C.N. J.O. Uzo dan W.T.H. Peregrine. 1993. Produksi Sayuran di Daerah Tropika. Gadjah Mada University Press. Yogyakarta.

Yuliasari, P. 2001. Uji Kemampuan Beberapa Spesies Trichoderma Dalam Menurunkan Nisbah Karbon dan Nitrogen Jerami Padi. Skripsi. Departemen Pendidikan Nasional Universitas Jendral Soedirman Fakultas Biologi. Purwokerto. 